\title{
Otolith measurements to estimate standard length of gobiid fish (Teleostei: Gobiiformes) from the Persian Gulf and Oman Sea
}

\author{
MAHDI IRANMANESH, MAJID ASKARI HESNI AND MOHAMMADREZA LASHKARI* \\ Department of Biology, Faculty of Sciences, Shahid Bahonar University of Kerman, Kerman, Iran \\ *Department of Biodiversity, Institute of Science and High Technology and Environmental Sciences, Graduate University \\ of Advanced Technology, Kerman, Iran \\ e-mail:mahesni@uk.ac.ir
}

\begin{abstract}
The relationship between morphometric characters (length, weight and height) of otolith and fish standard length was determined for six intertidal gobiid species from the northern Persian Gulf and Oman Sea. A total of 144 sagittal otoliths were extracted and anlysed from Periophthalmus waltoni, Boleophthalmus dussumieri, Scartelaos tenuis, Istigobius ornatus, Bathygobius meggitti and Trypauchen vagina. Regression equations were derived and found that there is no significant difference in regression coefficients between left and right otoliths of the species studied. Results of the study showed that otolith length $(\mathrm{OL})$ and height $(\mathrm{OH})$ could estimate standard length in all the species studied except in T. vagina, where the otolith weight gave the best estimate of standard length. Results clearly indicated that otolith dimensions of the gobiid fishes studied could provide information about the species and size.
\end{abstract}

Keywords: Body size, Gobiiformes, Otolith dimensions, Regression

Gobiid fishes belonging to the order Gobiiformes are the most diverse group of teleostean fishes that live in salt, brackish and freshwater environments of tropical to subtropical waters (Nelson et al., 2016). They inhabit mangrove swamps, coral reefs, mudflats and rocky ecosystems and are important prey for some top predators such as birds and some fishes (Polgar and Lim, 2011). Identification and determining the size of fish species are an important part of trophic studies of top predators that usually require the analysis and identification of hard remains found in food samples in the digestive system (Ayllon et al., 2006). Examining the digested food remains such as scales and bones from stomach of predators is a way to identify the prey (Venu and Kurup, 2002; Akhilesh et al., 2013) and in some cases, these structures gives unrealistic information about prey and their size (Longenecker, 2008).

Fish ear stones (otoliths) are reliable hard structures that can simplify identification of prey and provide useful information about fish biomass by specific regression analysis of otolith dimension and weight (Waessle et al., 2003; Aneesh Kumar et al., 2017). Otolith is not digested in stomach of predators, so this structure is used to determine type and size of fish species. Otolith is calcareous structure located in the inner ear of teleostean fish (Popper et al., 2005). Among three types of otoliths, sagittae have diverse morphology in most groups of fish and employed in taxonomy (Lombarte et al., 2018), paleontology (Reichenbacher et al., 2018) and fisheries management (Carlson et al., 2017).
Reconstruction of size and mass of fish species from the sagitta found in stomach contents or faeces of predators may provide significant contributions to the understanding about food chain of predators. Several studies have documented relationship between sagittal morphometry and fish body sizes (Longenecker, 2008; Jawad and Al-Mamry, 2012; Aneesh Kumar et al., 2017). However, studies on relationships between otolith morphometry and weight with fish body measurements are unavailable for intertidal gobiid fishes from the Persian Gulf and Oman Sea. So, this study was undertaken to provide information about otolith morphology and the relationship between otolith measurements and fish body size of six gobiid species from the coastal waters of the northern Persian Gulf and Oman Sea. The data may be useful for researchers who would study food webs of predators to identify and determine the size of prey from recovered otolith.

Sampling was done during 2016-2017 from five sites of Iranian coastal waters of the Persian Gulf and Oman Sea (Table 1). Collected specimens were immediately euthanised using clove oil, fixed in $10 \%$ formalin and preserved in $70 \%$ ethanol. In the laboratory, the fishes were identified upto species level following Murdy (1989) and Carpenter and Niem (2001) and six species viz., Periophthalmus waltoni Koumans, 1941; Boleophthalmus dussumieri Valenciennes, 1837; Scartelaos tenuis (Day, 1876); Istigobius ornatus (Ruppell, 1830); Bathygobius meggitti (Hora and Mukerji, 1936) and 
Table 1. Details of thespecies studied for otolith dimensions from five collection sites of the Iranian coastal waters of the Persian Gulf and Oman Sea

\begin{tabular}{|c|c|c|c|c|c|c|c|c|}
\hline \multirow[b]{2}{*}{ Family } & \multirow[b]{2}{*}{ Species } & \multicolumn{2}{|c|}{ Sampling sites } & \multirow[b]{2}{*}{$\mathrm{N}$} & \multirow[b]{2}{*}{$\begin{array}{l}\text { Otolith height } \\
(\mathrm{OH}) \text { (Range) }\end{array}$} & \multirow[b]{2}{*}{$\begin{array}{l}\text { Otolith length } \\
\text { (OL) (Range) }\end{array}$} & \multirow[b]{2}{*}{$\begin{array}{l}\text { Otolith weight } \\
\text { (OW) (Range) }\end{array}$} & \multirow[b]{2}{*}{$\begin{array}{l}\text { Standard length } \\
\text { (SL) (Range) }\end{array}$} \\
\hline & & Location & $\begin{array}{l}\text { Geographic } \\
\text { Coordinates }\end{array}$ & & & & & \\
\hline \multirow[t]{3}{*}{ Gobiidae } & B. meggitti & Oman Sea-Chabahar & $\mathrm{N} 25^{\circ} 20^{\prime}$ E $60^{\circ} 36^{\prime}$ & 15 & $0.98-1.88$ & $0.95-2.43$ & $0.7-3.1$ & $24.74-55.13$ \\
\hline & T. vagina & Persian Gulf-Bandar Abbas & $\mathrm{N} 27^{\circ} 05^{\prime}$ E $56^{\circ} 50^{\prime}$ & 18 & $3.5-4.6$ & $2.73-3.42$ & $11.6-23.2$ & $123.92-142$ \\
\hline & I. ornatus & Oman Sea-Chabahar & N $25^{\circ} 20^{\prime}$ E $60^{\circ} 36^{\prime}$ & 35 & $1.31-2.57$ & $1.28-2.7$ & $0.3-4.1$ & $21.33-78.77$ \\
\hline \multirow[t]{3}{*}{ Oxudercinae } & P. waltoni & Persian Gulf-Minab & $\mathrm{N} 27^{\circ} 05^{\prime}$ E $56^{\circ} 50^{\prime}$ & 39 & $2.36-4.13$ & $2.54-4.21$ & $2.3-20.8$ & $49.63-101.78$ \\
\hline & S. tenuis & Persian Gulf-Qeshm Island & N 265' E $56^{\circ} 12^{\prime}$ & 22 & $1.8-2.93$ & $2.29-3.38$ & $2.1-7.8$ & $57.15-106.73$ \\
\hline & B. dussumieri & Persian Gulf-Mahshahr & N $29^{\circ} 57^{\prime}$ E $48^{\circ} 36^{\prime}$ & 15 & $1.76-5.15$ & $1.92-4.76$ & $1.5-21.4$ & $37.59-123$ \\
\hline
\end{tabular}

$\mathrm{N}$ : Number of each specimens; Weight in mg; Otolith dimensions and standard length in mm

Trypauchen vagina (Bloch and Schneider, 1801) were recorded. In the next step, standard lengths (SL) of each specimens were measured using $0.01 \mathrm{~mm}$ digital vernier calipers (Hangzhou Maxwell Tools Co. Ltd, Zhejiang, China).

Sagitta was extracted from each side of the cranium, cleaned with $1 \% \mathrm{KOH}$ followed by distilled water, dried and stored in labelled tubes. A total of 144 sagittal otoliths from six species belonging to two family viz., Gobiidae and Oxudercidae were studied. Sagittae were photographed with Dino-lite camera mounted on a stereomicroscope (Olympus SZ-ST, Japan). Maximum otolith length (OL= Distance between the most anterior portion and the most posterior portion of otolith) and maximum otolith height $(\mathrm{OH}=$ Distance between the most dorsal portion and the most ventral portion of otolith) were measured to the nearest $0.01 \mathrm{~mm}$ by Dino capture software 2.1 (Fig. 1). The otolith weight (OW) was recorded to the nearest 0.01 mg using a digital scale.

In this study, we used power regressions $\left(y=a x^{b}\right)$ to determine the relationship between otolith measurements (otolith length, height and weight) and standard length of gobiid fishes as in earlier studies (Tuset et al., 2010; Valinassab et al., 2012; Gimenez et al., 2016). The parameters of the power regressions $a$ (intercept) and $b$ (slope) were expressed by linear regression of the log transformed data (Koutrakis and Tsikliras, 2003). The calculated parameters of left and right otoliths were compared using $t$-test to investigate for any differences between these.

General morphology of sagitta in the species studied are shown in Fig. 1. Otoliths in all gobiid species were characterised by median and mesial sulcus and absence of rostrum, antirostrum, pseudorostrum and pseudoantirostrum. The sagitta of I. ornatus (Fig. 1d) and S. tenuis (Fig. 1c) are slightly similar to each other, in both species the sagittal otolith is square to rectangular in shape and dorsal rime anteriority elevated. In I. ornatus, dorsal and ventral margins are slightly crenate but in S. tenuis dorsal and ventral margins are smooth. B. meggitti otolith (Fig. 1e) has rectangular shape and the whole margin is smooth. Otolith of T. vagina is $\mathrm{C}$ shape (Fig. 1f), moderately elongate and moderately thick with sulcus acusticus median and small. The otoliths of B. dussumieri (Fig. 1b) and P. waltoni (Fig. 1a) are almost similar, the main difference is that whole rime of otolith of $B$. dussumieri has an irregular ruble.

Overall information on the six gobiid species studied for otolith dimensions is provided in Table 1. Among the species studied, otolith of $T$. vagina was the largest $(\mathrm{OH}=$ $3.88 \pm 0.28 \mathrm{~mm} ; \mathrm{OL}=3.01 \pm 0.18 \mathrm{~mm} ; \mathrm{OW}=18 \pm 3.95 \mathrm{mg}$; $\mathrm{SL}=135.81 \pm 10.36 \mathrm{~mm})$ and otolith of $B$. meggitti was observed to be smallest $(\mathrm{OH}=1.48 \pm 0.26 \mathrm{~mm}$; $\mathrm{OL}=$ $1.66 \pm 0.37 \mathrm{~mm} ; \mathrm{OW}=1.32 \pm 0.61 \mathrm{mg} ; \mathrm{SL}=37.97 \pm 5.24 \mathrm{~mm})$.

There was no statistically significant difference in regression coefficients between right and left otoliths. The relationship between otolith dimensions and weight with standard length of the species studied are shown in Table 2. A high value of the coefficient of correlation $\left(\mathrm{R}^{2}=0.95\right)$ and the lowest $\mathrm{R}^{2}(0.54)$ were reported for otolith weight and otolith height of $T$. vagina respectively. Among the otolith parameters studied, otolith length calculated the best estimations of standard length of $P$. waltoni $\left(\mathrm{R}^{2}=\right.$ $0.88)$ and $B$. dussumieri $\left(\mathrm{R}^{2}=0.86\right)$. Otolith height of S. tenuis, I. ornatus and B. meggitti could determine more than $85 \%$ of fish standard length. Otolith weight was found to have high value of coefficient of correlation $\left(\mathrm{R}^{2}>0.80\right)$ in B. dussumieri, T. vagina and $S$. tenuis (Table 2). Among the otolith measurements, otolith length and height could predict more than $80 \%$ of the standard length of five species (Table 2).

Ear stone (otolith) is species-specific calcareous structure in the inner ear of the teleostean fish that has been used in ichthyology research (Schulz-Mirbach et al., 2019). Otolith morphology and morphometry are useful tools to identify fish species, paleontology research and to determine length-weight relationship of fishes (Sadighzadeh et al., 2012; Park et al., 2018; Reichenbacher et al., 2018). Although some studies have 


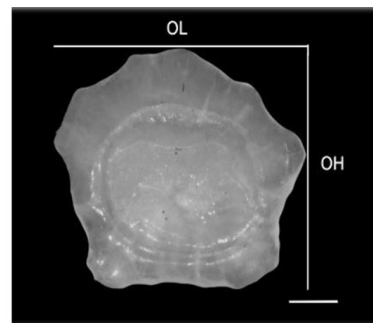

(a)

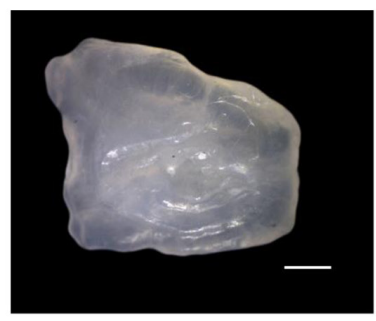

(c)

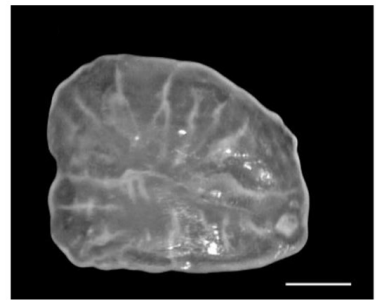

(e)

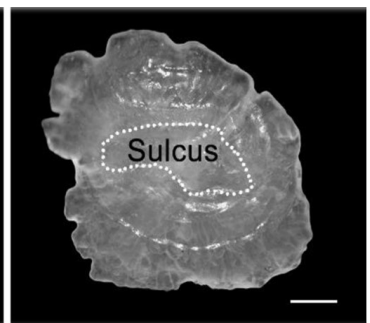

(b)

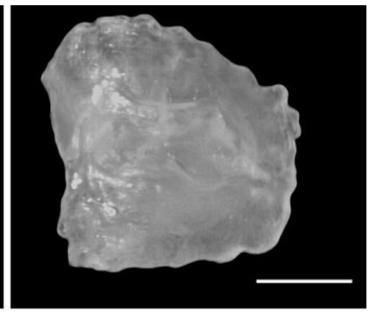

(d)

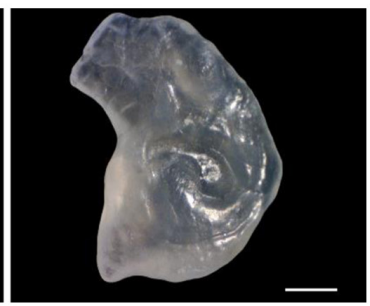

(f)
Fig. 1. Light microscope image of otolith from various species studied. (a) $\mathrm{OL}=$ Maximum otolith length; $\mathrm{OH}=$ Maximum otolith height. Family Oxudercinae: a - P. waltoni, b - B. dussumieri, c - S. tenuis. Family Gobiidae: d - I. ornatus, e - B. meggitti, $\mathrm{f}-T$. vagina. Scale bar $=1 \mathrm{~mm}$ been done to determine the relationship between otolith measurements and body size of fishes from the Persian Gulf and Oman Sea (Jawad et al., 2012; Dehghani et al., 2016), information on otolith of gobiid fish from this region was unavailable so far.

Results of this study showed otolith length and height could estimate more than $80 \%$ of the standard length of the species studied, except in T. vagina, where the otolith weight gave the best estimate of standard length (95\%). The strong correlation between otolith dimensions and body size of fish suggests that somatic growth has a significant effect on otolith growth (Munk, 2012).

Factors such as distribution area, sex, ontogeny and chemical parameters of water would affect the shape and dimension of otolith (Karakulak et al., 2006; Reichenbacher et al., 2009; Bignami et al., 2013). However, otolith is an accurate structure to identify and back calculate the prey biomass while examining stomach contents of predators (Battaglia et al., 2015; Lombarte et al., 2018).

In conclusion, our results showed that the shape and dimensions of the otolith (length, height and weight) of the gobiid fishes studied may be able to provide us with information about the species and size. Derivation of specific equations to determine standard length from otolith measurements for each species can provide basic information for feeding studies of the top predators in the Persian Gulf and Oman Sea.

Table 2. Regression parameters of relationship between otolith measurements and standard length of six species of gobiid fishes from the north Persian Gulf and Oman Sea

\begin{tabular}{lllllllll}
\hline \multirow{2}{*}{ Species } & \multicolumn{7}{c}{ Regression parameters } \\
\cline { 2 - 7 } & Relationship & $\mathrm{a}$ & $\mathrm{SE}(\mathrm{a})$ & $95 \%$ CL & $\mathrm{b}$ & $\mathrm{SE}$ (b) & $95 \%$ CL & $\mathrm{R}^{2}$ \\
\hline B. meggitti & OL vs. SL & 25.05 & 1.052 & $22.44-27.95$ & 0.812 & 0.094 & $0.60-1.01$ & 0.85 \\
& OH vs. SL & 25.09 & 1.047 & $22.68-27.75$ & 1.034 & 0.87 & $0.79-1.27$ & 0.87 \\
& OW vs. SL & 34.06 & 1.042 & $31.13-37.27$ & 0.432 & 0.09 & $0.22-0.64$ & 0.60 \\
\hline T. vagina & OL vs. SL & 72.76 & 1.08 & $60.93-86-8$ & 0.538 & 0.075 & $0.37-0.69$ & 0.75 \\
& OH vs. SL & 71.45 & 1.14 & $53.23-75.31$ & 0.45 & 0.1 & $0.23-0.67$ & 0.54 \\
& OW vs. SL & 79.31 & 1.029 & $74.620-84.3$ & 0.18 & 0.01 & $0.15-0.21$ & 0.95 \\
\hline I. ornatus & OL vs. SL & 16.50 & 1.09 & $14.04-20.53$ & 1.60 & 0.12 & $1.31-1.82$ & 0.83 \\
& OH vs. SL & 16.44 & 1.09 & $13.74-19.67$ & 1.76 & 0.12 & $1.49-2.02$ & 0.85 \\
& OW vs. SL & 39.82 & 1.04 & $36.14-42.98$ & 0.44 & 0.05 & $0.35-0.55$ & 0.72 \\
\hline P. waltoni & OL vs. SL & 19.42 & 1.078 & $16.65-22.64$ & 1.10 & 0.064 & $0.97-1.23$ & 0.88 \\
& OH vs. SL & 21.51 & 1.08 & $18.33-25.24$ & 1.09 & 0.071 & $0.94-1.23$ & 0.86 \\
& OW vs. SL & 39.81 & 1.065 & $34.98-45.31$ & 0.28 & 0.03 & $0.21-0.34$ & 0.69 \\
\hline S. tenuis & OL vs. SL & 21.71 & 1.17 & $13.06-25.32$ & 1.23 & 0.14 & $1.10-1.72$ & 0.81 \\
& OH vs. SL & 22.05 & 1.11 & $17.47-27.83$ & 1.49 & 0.12 & $1.22-1.75$ & 0.87 \\
& OW vs. SL & 41.47 & 1.07 & $35.40-48.77$ & 0.41 & 0.04 & $0.32-0.52$ & 0.80 \\
\hline B. dussumieri & OL vs. SL & 19.11 & 1.18 & $13.84-28.39$ & 1.14 & 0.123 & $0.86-1.40$ & 0.86 \\
& OH vs. SL & 23.35 & 1.16 & $17.04-33.38$ & 1.13 & 0.12 & $0.83-1.39$ & 0.85 \\
& OW vs. SL & 36.20 & 1.10 & $29.6-46.12$ & 0.39 & 0.04 & $0.28-0.47$ & 0.86 \\
\hline
\end{tabular}

OL: Otolith length, OH: Otolith height, OW: Otolith weight, SL: Standard length. $\mathrm{R}^{2}$ : Coefficient of determination, SE: Standard error, a: Intercept, b: Slope 


\section{Acknowledgements}

The authors thank M. Rajaei and N. Sabbah for their kind help during fish sampling.

\section{References}

Akhilesh, K. V., Bineesh, K. K., White, W. T., Shanis, C. P. R., Hashim, M., Ganga, U. and Pillai, N. G. K. 2013. Catch composition, reproductive biology and diet of the bramble shark Echinorhinus brucus (Squaliformes: Echinorhinidae) from the south-eastern Arabian Sea. J. Fish Biol., 83: 1112-1127. doi: 10.1111/jfb.12201.

Aneesh Kumar, K. V., Nikki, R., Oxona, K., Hashim, M. and Sudhakar, M. 2017. Relationships between fish and otolith size of nine deep $\square$ sea fishes from the Andaman and Nicobar waters, North Indian Ocean. J. Appl. Ichthyol., 33(6): 1187-1195. https://doi.org/10.1111/jai.13467.

Ayllon, F., Davaine, P., Beall, E. and Garcia-Vazquez, E. 2006. Dispersal and rapid evolution in brown trout colonising virgin Sub-Antarctic ecosystems. J. Evol. Biol., 19: 1352-1358. DOI: 10.1111/j.1420-9101.2005.01075.x.

Battaglia, P., Malara, D., Ammendolia, G., Romeo, T. and Andaloro, F. 2015. Relationships between otolith size and fish length in some mesopelagic teleosts (Myctophidae, Paralepididae, Phosichthyidae and Stomiidae). J. Fish Biol., 87(3): 774-782. doi: 10.1111/jfb.12744.

Bignami, S., Enochs, I. C., Manzello, D. P., Sponaugle, S. and Cowen, R. K. 2013. Ocean acidification alters the otoliths of a pantropical fish species with implications for sensory function. Proc. Natl. Acad. Sci. USA., 110(18): 7366-7370. https://doi.org/10.1073/pnas.1301365110.

Carlson, A. K., Phelps, Q. E. and Graeb, B. D. S. 2017. Chemistry to conservation: Using otoliths to advance recreational and commercial fisheries management. J. Fish Biol., 90(2): 505-527. doi: 10.1111/jfb.13155.

Carpenter, K. E. and Niem, V. H. 2001. FAO species identification guide for fishery purposes. The living marine resources of the Western Central Pacific. Volume 6. Bony fishes part 4 (Labridae to Latimeriidae), estuarine crocodiles, sea turtles, sea snakes and marine mammals. FAO Library, Food and Agriculture Organisation, Rome, Italy.

Dehghani, M., Kamrani, E., Salarpouri, A. and Sharifian, S. 2016. Otolith dimensions (length, width), otolith weight and fish length of Sardinella sindensis (Day, 1878), as index for environmental studies, Persian Gulf, Iran. Mar. Biodivers. Rec., 9(1): p. 44.

Gimenez, J., Manjabacas, A., Tuset, V. M. and Lombarte, A. 2016. Relationships between otolith and fish size from Mediterranean and north $\square$ eastern Atlantic species to be used in predator-prey studies. J. Fish Biol., 89(4): 2195-2202. https://doi.org/10.1111/jfb.13115.

Jawad, L. A. and Al-Mamry, J. M. 2012. Relationship between fish length and otolith dimensions in the carangid fish (Carangoides coeruleopinnatus Rüppell, 1830) collected from the Sea of Oman. J. Fish. Sci., 6(3): 203-208.
Karakulak, F. S., Erk, H. and Bilgin, B. 2006. Length-weight relationships for 47 coastal fish species from northern Aegean Sea, Turkey. J. Appl. Ichthyol., 22: 274-278. https://doi.org/10.1111/j.1439-0426.2006.00736.x.

Koutrakis, E. and Tsikliras, A. 2003. Length-weight relationships of fishes from three northern Aegean estuarine systems (Greece). J. Appl. Ichthyol., 19(4): 258-260. https://doi. org/10.1046/j.1439-0426.2003.00456.x.

Lombarte, A., Miletic, M., Kovacic, M., Otero $\square$ Ferrer, J. L. and Tuset, V. M. 2018. Identifying sagittal otoliths of Mediterranean Sea gobies: variability among phylogenetic lineages. J. Fish Biol., 92(6): 1768-1787. https://doi org/10.1111/jfb.13615.

Longenecker, K. 2008. Relationships between otolith size and body size for Hawaiian Reef Fishes. Pac. Sci., 62(4): 533-539.

Munk, K. M. 2012. Somatic-otolith size correlations for 18 marine fish species and their importance to age determination. Alaska Department of Fish and Game Regional Information Report No. 5J12-13, Juneau, Alaska.

Murdy, E. O. 1989. A taxonomic revision and cladistic analysis of the oxudercine gobies (Gobiidae: Oxudercinae). Records of the Australian Museum(Suppl.), 11: 1-93.

Nelson, J. S., Grande, T. C. and Wilson, M. V. 2016. Fishes of the world, $5^{\text {th }}$ edn. John Wiley and Sons, New Jersey, USA.

Park, J. M., Gaston, T. F., Riedel, R. and Williamson, J. E. 2018. Biometric relationships between body and otolith measurements in nine demersal fishes from north $\square$ eastern Tasmanian waters, Australia. J. Appl. Ichthyol., 34(4): 801-805. https://doi.org/10.1111/jai.13612.

Polgar, G. and Lim, R. 2011. Mudskippers: Human use, ecotoxicology and biomonitoring of mangrove and other soft bottom intertidal ecosystems. Mangroves: Ecology, biology and taxonomy, Nova Science Publishers, New York, USA, p. 51-86.

Popper, A. N., Ramcharitar, J. and Campana, S. E. 2005. Why otoliths? Insights from inner ear physiology and fisheries biology. Mar. Freshw. Res., 56(5): 497-504.

Reichenbacher, B., Gregorova, R., Holcova, K., Sanda, R., Vukic, J. and Prikryl, T. 2018. Discovery of the oldest Gobius (Teleostei, Gobiiformes) from a marine ecosystem of Early Miocene age. J. Syst. Palaeontol., 16(6): 493-513. https://doi.org/10.1080/14772019.2017.1313323.

Reichenbacher, B., Kamrani, E., Esmaeili, H. R. and Teimori, A. 2009. The endangered cyprinodont Aphanius ginaonis (Holly, 1929) from southern Iran is a valid species: Evidence from otolith morphology. Environ. Biol. Fishes, 86: 504-521.

Sadighzadeh, Z., Tuset, V. M., Valinassab, T., Dadpour, M. R. and Lombarte, A. 2012. Comparison of different otolith shape descriptors and morphometrics for the identification 
of closely related species of Lutjanus spp. from the Persian Gulf. Mar. Biodivers. Rec., 8(9): 802-814. https://doi.org/1 $0.1080 / 17451000.2012 .692163$.

Schulz-Mirbach, T., Ladich, F., Plath, M. and Heß, M. 2019. Enigmatic ear stones: What we know about the functional role and evolution of fish otoliths. Biol. Rev., 94(2): 457-482. https://doi.org/10.1111/brv.12463.

Tuset, V. M., Piretti, S., Lombarte, A. and Gonzalez, J. A. 2010 Using sagittal otoliths and eye diameter for ecological characterisation of deep-sea fish: Aphanopus carbo and A. intermedius from NE Atlantic waters. Sci. Mar., 74: 807-814. doi: 10.3989/scimar. 2010.74n4807.
Valinassab, T., Seifabadi, J., Homauni, H. and Afraie Bandpei, M. A. 2012. Relationships between fish size and otolith morphology in ten clupeids from the Persian Gulf and Gulf of Oman. Cybium, 36: 505-509.

Venu, S. and Kurup, B. M. 2002. Distribution and biology of the deep sea fish Psenopsis cyanea (Alcock) inhabiting continental slope of the west coast of India. J. Mar. Biol. Ass. India, 44: 176-186.

Waessle, J. A., Lasta, C. A. and Favero, M. 2003. Otolith morphology and body size relationships for juvenile Sciaenidae in the Río de la Plata Estuary (35-36 S). Sci. Mar., 67(2): 233-240. 